\title{
Ophthalmologica
}

Bechara, E. 59

Bruinsma, M. 51

Cattin, P.C. 11

de Paula Fiod Costa 41, 59

Dib, E. 59, 68

Enaida, H. 27

Farah, M.E. 41, 59, 68

Frank, H. 51

Freymüller, E.H. 59

Gabel, D. 51

Grisanti, S. 21

Hachisuka, Y. 27

Haritoglou, C. 3

Henrich, P.B. 11
Ikeda, Y. 27

Ishibashi, T. 27

Kadonosono, K. 27

Lima Filho, A.A.S. 59

Liu, Z. 33

Loparic, M. 11

Lourenço, A. 59

Lüke, J. 21

Lüke, M. 21

Maia, A. 68

Maia, M. 41, 59, 68

Marin-Castaño, M.E. 41

Melles, G.R.J. 51

Melo, G.B. 68

Meyer, C.H. 33, 59, 73

Mohr, A. 51

Monnier, C.A. 11
Nakao, S. 27

Oellerich, S. 51

Oshima, Y. 27

Penha, F.M. 41, 59, 68

Pons, M. 41

Rodrigues, E.B. 41, 59, 68

Saxena, S. 73

Schumann, R.G. 3

Stanzel, B.V. 33

Ueno, A. 27

Yoshida, S. 27

\section{Subject Index Vol. 230, Suppl. 2, 2013}

Apoptosis 41

Atomic force microscopy 3, 11

Biochemical analysis 59

Biocompatibility 21

Blood-retina barrier 33

Brilliant blue 3, 68

- - green 51

- $\quad$ G staining 27

Cell culture 33

- viability 41

Chromaticity analysis 11

Chromovitrectomy 3, 11, 33, 59, 73

Color contrast 11

Decomposition products 59

Dyes 21

Electron microscopy 3

Electroretinogram 21
Endoillumination 73

Epiretinal membrane 3,51

Ex vivo model 21

Indocyanine green 3, 59

Infracyanine green 59

Internal limiting membrane $3,11,27$, $51,59,68$

Light-emitting diode 73

Macular hole 68

- surgery 51

Material properties 11

Osmolarity 59

Polyethylene glycol 51

Precipitation 59

Quenchers 59
Retina 21, 59, 68

Retinal debris 3

- pigment epithelium 33, 41

Sharp cut filter 27

Tight junctions 33

Transepithelial electrical resistance 33

Trypan blue 51

Viewing filter system 27

Vital dye 3

- dyes 41

Vitrectomy 59, 68

Vitreoretinal interface 3

- surgery 73 